\title{
A Review of Ancillary Tests in Evaluating Brain Death
}

\author{
Manraj K. S. Heran, Navraj S. Heran, Sam D. Shemie
}

\begin{abstract}
The neurological determination of death (NDD) is primarily considered to be clinical. However, situations may arise where confounding factors make this clinical assessment difficult or impossible. As a result, ancillary tests have been developed in order to aid in the confirmation of brain death. As assessment of neuronal electrical activity; electroencephalography (EEG) is no longer recommended in this determination, tools assessing cerebral perfusion, as reflected by the presence or absence of cerebral blood flow $(\mathrm{CBF})$, are the mainstay of NDD. The preferred ancillary test currently is Hexamethylpropylene amine oxime-single photon emission computed tomography (HMPAO SPECT) radionuclide angiography. When this is not available, or is equivocal, 4-vessel cerebral angiography can be used to determine the presence or absence of intracranial blood flow. However, as cerebral angiography has its own limitations, other techniques are sought by physicians in the Intensive Care and Neuro-intensive Care settings to replace cerebral angiography. In this article, we briefly review the history of diagnosis of brain death, pathophysiologic issues in making this determination, and currently available CBF imaging techniques, discussing each in turn with respect to their utility in the diagnosis of brain death.
\end{abstract}

RÉSUMÉ: Analyse des tests d'appoint dans l'évaluation de la mort cérébrale. La détermination neurologique de la mort (DNM) est considérée comme étant basée principalement sur la clinique. Cependant, il existe des situations où des facteurs confondants rendent cette évaluation clinique difficile, voir même impossible. Des tests d'appoint ont donc été mis au point afin de faciliter ce diagnostic. L'évaluation de l'activité électrique neuronale (ÉEG) n'est plus recommandée. Les outils permettant d'évaluer la perfusion cérébrale, soit la présence ou l'absence de flux sanguin cérébral (FSC), sont devenus les test de choix pour déterminer la DNM. L'épreuve d'appoint de choix actuellement est l'angiographie isotopique (SPECT HMPAO). Quand cet examen n'est pas disponible ou que ses résultats sont équivoques, une angiographie cérébrale des 4 vaisseaux peut être utilisée pour déterminer la présence ou l'absence de FSC. Cependant, l'angiographie cérébrale a ses propres limites et les médecins oeuvrant à l'unité de soins intensifs ou de soins intensifs neurologiques ont recours à d'autres techniques pour y suppléer. Nous analysons brièvement l'historique du diagnostic de mort cérébrale, les aspects physiopathologiques de la DNM et les techniques d'imagerie qui sont disponibles pour l'évaluation du FSC. Nous discutons de l'utilité de chacune de ces techniques pour établir un diagnostic de mort cérébrale.

Can. J. Neurol. Sci. 2008; 35: 409-419

Brain death. The very concept has stirred much debate for decades. Referred to as "coma depasse" (beyond coma) by Mollaret and Goulon in $1959,{ }^{1}$ the first formalized definition of brain death was by the Ad Hoc Committee of the Harvard Medical School in $1968,{ }^{2}$ Since then there has been a greater understanding of neuronal function and mechanisms of brain cell injury, ${ }^{3,4}$ with the emergence of a concept of "death of the person rather than the body", as described by Bonetti et al. ${ }^{5}$ Brain death is now considered as complete and irreversible loss of brain function, ${ }^{5-10}$ or as the Canadian Neurocritical Care Group defined it in 1999, "the irreversible loss of the capacity for consciousness combined with the irreversible loss of all brainstem functions including the capacity to breathe". ${ }^{11}$
Articles, such as those by Baron et $\mathrm{al}^{12}$ and Bernat, ${ }^{13}$ nicely review the concept of brain death, as well as discuss continuing

From the Division of Neuroradiology, Vancouver General Hospital (MKSH),

Department of Radiology, Children's and Women's Health Center of British Colombia (MKSH), University of British Columbia, Vancouver; Division of Neurosurgery, Royal Columbian Hospital (NSH), New Westminster, British Columbia; Division of Critical Care, Montreal Children's Hospital (SDS), McGill University, Faculty of Arts, University of Ottawa, Canadian Council for Donation and Transportation, Ottawa, Ontario.

Received October 12, 2007. Final Revisions Submitted April 11, 2008. Correspondence to: Manraj K.S. Heran, Department of Radiology, Vancouver General Hospital, 899 W. 12th Avenue, Vancouver, British Columbia, V5Z 1M9, Canada. 
areas of controversy, such as whole-brain death versus death of the brain stem. As modern medicine can now allow survival of an individual in situations once considered hopeless, knowing the evolution of the concept of brain death is important in order to keep perspective on the person, rather than the body.

\section{Methods}

A literature review based on a MEDLINE search of relevant articles between January 1966 and October 2006 was conducted. Keywords included the following: brain death, neurological determination of death, computed tomography (CT), magnetic resonance imaging (MRI), perfusion, xenon, transcranial Doppler, radionuclide, cerebral blood flow, angiography, stroke, ischemia, and infarction. Search parameters were combined to find articles relevant to the discussion of perfusion and/or angiographic imaging in the evaluation of brain death.

\section{Principles of Cerebral Perfusion}

The cerebral circulation refers to the blood vessels in the brain, both arterial and venous. Cerebral blood flow (CBF) refers to the amount of blood that enters the brain over a period of time, and is a specific parameter describing cerebral perfusion. The human brain uses approximately $20 \%$ of the cardiac output. $\mathrm{CBF}$ is tightly regulated to meet the brain's metabolic demands, and on average must be maintained at a flow of 50 milliliters of blood per 100 grams of brain tissue per minute $(50 \mathrm{~mL} / 100 \mathrm{gm} / \mathrm{min}) .{ }^{14-19}$ With reduction in $\mathrm{CBF}$, there is proportionately increasing oxygen extraction from delivered blood. Furthermore, in brain starving for oxygen, at a threshold of greater than $50 \%$ reduction in $\mathrm{CBF}$, or close to the level of $\mathrm{CBF}$ reduction associated with clinical changes, there is an increase in lactate production from anaerobic metabolism. ${ }^{20,21}$ Complete suppression of protein synthesis appears to occur below CBF values of $35 \mathrm{~mL} / 100 \mathrm{~g} / \mathrm{min}$. Glucose utilization transiently increases between flow rates of $25-35 \mathrm{~mL} / 100 \mathrm{~g} / \mathrm{min}$, with a precipitous decline below this range. Below 25 $\mathrm{mL} / 100 \mathrm{~g} / \mathrm{min}$, tissue acidosis becomes more pronounced as anaerobic glycolysis dominates, and intracellular phosphocreatine and ATP also decline. ${ }^{16}$ The CBF must drop to less than $20 \mathrm{~mL} / 100 \mathrm{gm} / \mathrm{min}$ to get ischemic neuronal activity reduction and reversible neuronal changes. ${ }^{22}$ This is when a person typically becomes clinically symptomatic of their ischemic neurovascular condition. Experimental studies in cats ${ }^{23}$ and primates ${ }^{24}$ and clinical studies performed during carotid endarterectomy surgery in humans ${ }^{25}$ have shown loss of spontaneous and evoked electrical activity when CBF values fall below $16-18 \mathrm{~mL} / 100 \mathrm{~g} / \mathrm{minute}$. Cerebral blood flow values less than $10 \mathrm{~mL} / 100 \mathrm{gm} / \mathrm{min}$ result in irreversible ischemic neuronal damage within minutes, as reflected by membrane failure. ${ }^{14-17,26}$ The CBF values between $10-20 \mathrm{~mL} / 100 \mathrm{gm} / \mathrm{min}$ are deemed the "ischemic penumbra", and represent neuronal tissue which may potentially be salvaged, if flow restoration occurs before irreversible damage sets in. On the other hand, $\mathrm{CBF}$ in excess of $50 \mathrm{mLl} / 100 \mathrm{~g} / \mathrm{min}$ is termed hyperemia and can contribute to an increase in intracranial pressure (ICP) which can secondarily lead to ischemia. ${ }^{21}$

Cerebral blood flow is determined by a number of factors, including blood viscosity, blood vessel caliber, and cerebral perfusion pressure (CPP). The CPP is the net pressure of blood flowing into the brain and is determined by subtracting the ICP from the systemic mean arterial blood pressure (MAP). ${ }^{27}$ Cerebral blood vessels are able to self-regulate CBF through autoregulation, ${ }^{27}$ a process in which blood vessels constrict when systemic blood pressure is raised and dilate when blood pressure is lowered. ${ }^{28}$ When pressures are outside the range of 60 to 150 $\mathrm{mmHg}$, the blood vessels' ability to autoregulate pressure through dilation and constriction is lost, and cerebral perfusion is determined by blood pressure alone, a situation called pressurepassive flow. ${ }^{28}$ Similar loss of autoregulatory ability can also be seen in injured brain, potentially leading to sudden increase or decrease in the total intracranial intravascular blood volume, and even leakage into the brain due to blood-brain barrier dysfunction. In sudden or extreme situations, this may contribute to ICP variation affecting cerebral blood flow. Arterioles also constrict and dilate in response to different metabolite concentrations in the local environment. ${ }^{28}$ For example, they dilate in response to higher levels of carbon dioxide and $\mathrm{H}+$ in the blood. Although the Lund protocol allows for CPP to be as low as $50 \mathrm{mmHg}$ in adults and $40 \mathrm{mmHg}$ in children for short periods of time, it is widely accepted that CPP in an adult human cannot go below $60-70 \mathrm{mmHg}$ for a sustained period of time without causing ischemic brain injury. ${ }^{27,29,30}$

\section{The Role of Ancillary Tests}

Brain death is a clinical diagnosis. As such, many authors have previously outlined the clinical criteria for brain death. ${ }^{13,31,32}$ Important aspects of the clinical examination in brain death, such as apnea testing, have recently been reviewed. ${ }^{30}$ However, many confounding factors may exist (Table 1). Though the clinical diagnosis of brain death may be difficult in young children and neonates, ancillary testing is not

Table 1: Confounding factors in the clinical diagnosis of brain death

1.) In situations in which clinical criteria cannot be reliably applied

a. Cranial nerves cannot be adequately examined

i. Trauma to eyes

ii. Trauma to middle and/or inner ears

iii. Cranial neuropathies

b. Neuromuscular paralysis

i. Neuropathies

ii. Drug-induced

c. Pharmacologic paralysis of papillary pupillary responses

d. Heavy sedation

e. When apnea test not valid (such as in high carbon dioxide retainers)

f. Profound metabolic and endocrine disturbances that are difficult to reverse

2.) In young children 
routinely recommended in this setting due to confounding factors on $\mathrm{CBF}$ assessment. Shemie et al discuss such issues in young children and neonates. ${ }^{31}$ However, in the older child and adult, features of the clinical exam may not be able to be safely implemented. It may not be possible for a patient to undergo an apnea test. Patients with eye injuries may not be amenable to appropriate assessment of pupillary, corneal, or vestibulo-reflex testing. Those with perforated tympanic membranes will not be able to undergo ice water caloric testing for vestibulo-ocular reflexes. As a result, although confirmatory testing of cerebral blood flow is not mandatory in North America in the clinical diagnosis of brain death, there has been much interest in ancillary tests for aiding in the diagnosis of brain death when specific components of the clinical examination cannot be reliably performed. ${ }^{8,31}$ Indeed, in certain European, Central and South American, and Asian countries, legislation requires ancillary tests as part of the diagnostic criteria for establishing brain death..$^{32,34}$

\section{The Ideal Ancillary Test}

The ideal ancillary test must fulfill several criteria (Table 2). There must be no false positives (ie, no cerebral blood flow, yet the individual survives), and very few false negatives. ${ }^{13}$ In addition, testing that could be done at the bedside would be best, as this would avoid transferring potentially hemodynamically unstable patients from the Intensive Care Unit (ICU). ${ }^{35}$ Currently, there is no ideal ancillary test. The objective of ancillary testing is to determine the point of cessation of cerebral arterial circulation. ${ }^{36-38}$ Through considered application of ancillary tests, cases where the clinical diagnosis of brain death is confounded can be assessed. Earlier determination of brain death may then allow for avoidance of protracted stays in the ICU, and potentially expedite organ donation before tissue viability becomes a concern.

\section{Types of Ancillary Testing in Brain Death}

There are several types of ancillary tests currently available that can assess cerebral perfusion and its effects on the brain

\section{Table 2: Qualities of the Ideal Ancillary Test}

No false-positives
Readily available
Rapid
Safe
Portable
Non-invasive
Inexpensive
Independently sufficient to establish brain death
Not susceptible to external/internal confounding factors
Standardized in technology, technique, and classification of
$\quad$ results

parenchyma. These tests differ on the basis of availability, reproducibility, reliability, and sensitivity. Whereas certain tests such as radionuclide angiography are relatively easy to administer, other examinations, such as four-vessel cerebral angiography, require transportation of the patient to specialized areas of the hospital outside the ICU and involve subspecialty expertise in order to perform and analyze the examinations. The decision to use one ancillary test over another is therefore dependent on many factors, including safety of the patient, sensitivity and specificity of the examination, and availability of the ancillary test. Existing literature regarding the use of some of these tests in the setting of brain death can be found in Appendix A, while Appendix B provides a comparative overview of existing tests assessing cerebral perfusion. In short, though several of the ancillary tests currently available meet many of the criteria outlined in Table 2, none are ideal.

\section{Examinations Assessing Brain Structural Changes Computed Tomography}

Computed tomography is a powerful modality for evaluating neurologic disorders. It is readily available, rapidly performed, and does not necessarily require subspecialty expertise to interpret. In the setting of brain death, the classical non-contrast CT head (NCCT) findings have been well described. ${ }^{39}$ These include: diffuse cerebral edema, loss of differentiation between the gray and white matter structures globally, and herniation patterns resulting from the cerebral edema. Dominguez-Roldan et $\mathrm{al}^{40}$ concluded that two signs on NCCT were significantly associated with brain death. These were midline shift of greater than $10 \mathrm{~mm}$, and compression of the ambient cistern. Geraghty and Torbey ${ }^{41}$ conducted a study assessing the prognosis of patients becoming comatose after cardiac arrest. In their article, they describe the use of a gray matter-to-white matter Hounsfield attenuation ratio (GM:WM) to predict brain death, with a cutoff of 1.18 . Using this cutoff, $100 \%$ of those patients with GM:WM ratios of $<1.18$ died, whereas $54 \%$ of those above this cutoff survived. However, despite the ability of NCCT to depict changes reflecting parenchymal injury, it is not sensitive or specific enough to be used as an ancillary test for determination of brain death as, in many cases, there is no midline shift and the GM:WM ratios may initially not be significantly abnormal, even though brain death has occurred.

The concept of using an intravenous contrast-enhanced CT head examination (CECT) in the assessment for brain death is not new. ${ }^{42-44}$ Tan et $\mathrm{al}^{44}$ directly compared cerebral angiography with dynamic NCCT and CECT examinations in five patients clinically confirmed as brain dead. They found that the intracranial circulatory arrest associated with brain death in these patients resulted in no contrast opacification intracranially, whereas normal circulation was present in the scalp (supplied by external carotid artery branches). Dupas et $\mathrm{al}^{43}$ also demonstrated stagnation and arrest of contrast flow at the level of the internal carotid and vertebral arteries on their two-phase helical CT examinations. However, they also confirmed that the superior sagittal sinus could be seen in up to $50 \%$ of their study population, presumably opacifying via meningeal artery perfusion or trans-diploic emissary veins draining the scalp tissues to the superior sagittal sinus. The internal cerebral veins, 
Appendix A: Existing Human Studies Regarding Alternative Ancillary Tests to Cerebral Angiography and HMPAO-SPECT for CBF Determination in the Setting of Brain Death

\begin{tabular}{|c|c|c|c|c|c|c|}
\hline Test & Author & Year & $\begin{array}{c}\text { Number of } \\
\text { subjects }\end{array}$ & Type of study & Principle finding & $\begin{array}{c}\text { Comparative } \\
\text { standard** }\end{array}$ \\
\hline \multirow[t]{3}{*}{ CTA } & Yu et al & 2005 & 1 & Case report & Absence of intracranial blood flow* & Clinical \\
\hline & Qureshi & 2004 & 2 & Case report & Absence of intracranial blood flow* & CTP \\
\hline & Leclerc et al & 2006 & 15 & Prospective series & $\begin{array}{l}\text { Absence of cortical MCA branch } \\
\text { arteries and internal cerebral vein }\end{array}$ & Clinical \\
\hline CTP & $\mathrm{n} / \mathrm{a}$ & $\mathrm{n} / \mathrm{a}$ & $\mathrm{n} / \mathrm{a}$ & $\mathrm{n} / \mathrm{a}$ & $\mathrm{n} / \mathrm{a}$ & $\mathrm{n} / \mathrm{a}$ \\
\hline \multirow[t]{5}{*}{ MRA } & Aichner et al & 1992 & 3 & $\begin{array}{l}\text { Retrospective case } \\
\text { series }\end{array}$ & Absence of intracranial blood flow* & Clinical \\
\hline & Ishii et al & 1996 & 4 & $\begin{array}{l}\text { Retrospective case } \\
\text { series }\end{array}$ & Absence of intracranial blood flow* & HMPAO-SPECT \\
\hline & Matsumura et al & 1996 & 15 & Prospective series & Absence of intracranial blood flow* & Clinical and DSA \\
\hline & $\begin{array}{l}\text { Lovblad and } \\
\text { Bassetti }\end{array}$ & 2000 & 1 & Case report & Absence of intracranial blood flow* & Clinical \\
\hline & Karantanas et al & 2002 & 30 & Prospective series & Absence of intracranial blood flow* & Clinical \\
\hline MRP & $\mathrm{n} / \mathrm{a}$ & $\mathrm{n} / \mathrm{a}$ & $\mathrm{n} / \mathrm{a}$ & $\mathrm{n} / \mathrm{a}$ & $\mathrm{n} / \mathrm{a}$ & $\mathrm{n} / \mathrm{a}$ \\
\hline \multirow[t]{4}{*}{$\mathrm{XeCT}$} & Thompson et al & 1986 & 10 & Prospective series & Absence of intracranial blood flow* & $\begin{array}{l}\text { Dynamic } \\
\text { radionuclide } \\
\text { scintigraphy } \\
\end{array}$ \\
\hline & Darby et al & 1987 & 9 & $\begin{array}{l}\text { Retrospective case } \\
\text { series }\end{array}$ & $\begin{array}{l}<5 \mathrm{~mL} / 100 \mathrm{~g} / \mathrm{min} \text { threshold for } \\
\mathrm{CBF} \text { values compatible with brain } \\
\text { death }\end{array}$ & $\begin{array}{l}\text { Variable: EEG, } \\
\text { angio, dynamic } \\
\text { radionuclide } \\
\text { scintigraphy }\end{array}$ \\
\hline & Ashwal et al & 1989 & 21 & $\begin{array}{l}\text { Retrospective case } \\
\text { series }\end{array}$ & $\begin{array}{l}<10 \mathrm{~mL} / 100 \mathrm{~g} / \mathrm{min} \text { threshold for } \\
\text { clinical brain death^} \\
<5 \mathrm{~mL} / 100 \mathrm{~g} / \mathrm{min}^{\wedge} \text { consistent with } \\
\text { no flow as demonstrated by } \\
\text { radionuclide techniques }\end{array}$ & $\begin{array}{l}\text { Dynamic } \\
\text { radionuclide } \\
\text { scintigraphy }\end{array}$ \\
\hline & Pistoia et al & 1991 & 30 & $\begin{array}{l}\text { Retrospective case } \\
\text { series }\end{array}$ & $\begin{array}{l}<5 \mathrm{~mL} / 100 \mathrm{~g} / \mathrm{min} \text { threshold for } \\
\mathrm{CBF} \text { values compatible with brain } \\
\text { death }\end{array}$ & $\begin{array}{l}\text { Dynamic } \\
\text { radionuclide } \\
\text { scintigraphy }\end{array}$ \\
\hline
\end{tabular}

*absence of intracranial blood flow refers to no visualization of the vertebrobasilar circulation or the anterior circulation above the level of the carotid siphons in those clinically determined to be brain dead; **all assessments were done with clinical brain death as the primary inclusion criterion; ^ in infants and children older than one month; $\mathrm{n} / \mathrm{a}$ - none available

vein of Galen, and straight sinus were never opacified in their study.

\section{Magnetic Resonance Imaging}

Magnetic resonance imaging (MRI) has revolutionized neuroimaging and its use in evaluating virtually every type of neuropathological state is beyond debate. Much like in CT, the classical findings on MRI in clinically confirmed brain death include brain swelling, various herniation patterns, obliteration of the cerebrospinal fluid (CSF) spaces, and compression of the ventricular system. ${ }^{32,45,46}$ The ratio of signal intensity between the gray and white matter has been noted to increase after the clinical diagnosis of brain death ${ }^{45,46}$ and serial examinations performed in a patient proceeding on to clinical brain death have demonstrated these temporal changes in progressive brain failure. ${ }^{47}$ As MRI is superior to CT in the evaluation of flowing blood, this feature has been examined as well. Jones and Barnes $^{48}$ confirmed absent $\mathrm{CBF}$ on flow-sensitive gradient-echo sequences. This lack of intracranial arterial flow voids has also been documented by others. ${ }^{32,46,49}$ Diffusion-weighted imaging (DWI) may also be a potentially useful tool in the assessment of brain death. McKinney et $\mathrm{al}^{50}$ nicely reviewed the histopathologic correlation of brain tissue infarction with DWI findings and Kumada et al found a significant drop in the apparent diffusion coefficient (ADC) values of the involved parenchyma in those with a clinical diagnosis of brain death, ${ }^{51}$ also shown by Nakahara et al. ${ }^{52}$ It is suggested that the white matter may demonstrate greater ADC reduction following brain death than the gray matter. ${ }^{52,53}$ However, DWI lacks the sensitivity and specificity necessary to accurately predict global brain function on the basis of regional DWI changes.

Magnetic resonance spectroscopy (MRS) has also been applied in the evaluation of brain death..$^{38,47,54-56}$ The MRS findings have been variable, with no characteristic pattern typical of brain death. Though certain derangements of metabolites, such as the production of lactate, would be expected as neuronal 


\section{Appendix B: Comparison of Ancillary Tests for Determination of Cerebral Blood Flow in the Setting of Brain Death}

\begin{tabular}{|c|c|c|c|c|c|}
\hline Test & Definition & $\begin{array}{l}\text { Minimum Flow } \\
\text { Limit } \\
(\mathrm{mL} / 100 \mathrm{~g} / \mathrm{min})\end{array}$ & Advantages & Disadvantages & Consensus \\
\hline$D S A$ & $\begin{array}{l}\text { Digital } \\
\text { subtraction } \\
\text { angiography }\end{array}$ & 0 & Direct visualization of $\mathrm{CBF}$ & $\begin{array}{l}\text { Invasive } \\
\text { Exposure to iodinated contrast } \\
\text { Not readily available } \\
\text { Not portable, Expensive }\end{array}$ & $\begin{array}{l}\text { Reference standard for } \\
\text { NDD assessment } \\
\text { Not preferred test due to } \\
\text { invasiveness }\end{array}$ \\
\hline SPECT & $\begin{array}{l}\text { Single photon } \\
\text { emission } \\
\text { computed } \\
\text { tomography }\end{array}$ & 5 & $\begin{array}{l}\text { Widely available } \\
\text { Portable, Low cost } \\
\text { Whole brain coverage }\end{array}$ & $\begin{array}{l}\text { Not quantitative } \\
\text { Poor spatial resolution }\end{array}$ & $\begin{array}{l}\text { Reference standard for } \\
\text { NDD assessment }\end{array}$ \\
\hline PET & $\begin{array}{l}\text { Positron } \\
\text { emission } \\
\text { tomography }\end{array}$ & 0 & $\begin{array}{l}\text { Quantitative, Can assess } \\
\text { multiple factors, including } \\
\text { oxygen consumption, by using } \\
\text { different radioligands } \\
\text { Repeated measurements } \\
\text { possible, Whole brain coverage }\end{array}$ & $\begin{array}{l}\text { Impractical for everyday use } \\
\text { Expensive } \\
\text { Not portable }\end{array}$ & $\begin{array}{l}\text { Reference standard for } \\
\text { CBF assessment } \\
\text { Not useful in NDD }\end{array}$ \\
\hline$X e C T$ & $\begin{array}{l}\text { Xenon } \\
\text { computed } \\
\text { tomography }\end{array}$ & 0 & $\begin{array}{l}\text { Quantitative } \\
\text { Allows simultaneous CT-based } \\
\text { imaging techniques } \\
\text { Can be repeated within } 10 \\
\text { minutes }\end{array}$ & $\begin{array}{l}\text { Only available in a few academic } \\
\text { centers as not FDA approved, Not } \\
\text { portable, Limited brain coverage }(6 \\
\mathrm{cm}) \text {, Delivery of Xenon gas may } \\
\text { present challenges }\end{array}$ & $\begin{array}{l}\text { Reference standard for } \\
\text { CBF assessment } \\
\text { Not useful in NDD due tc } \\
\text { limited availability }\end{array}$ \\
\hline$M R A$ & $\begin{array}{l}\text { Magnetic } \\
\text { resonance } \\
\text { angiography }\end{array}$ & $\begin{array}{l}\text { Dependent on } \\
\text { technique of } \\
\text { acquisition, but } \\
\text { considered very } \\
\text { low }(<10)\end{array}$ & $\begin{array}{l}\text { Readily available } \\
\text { No contrast necessary } \\
\text { Can be combined with other } \\
\text { MR-based techniques }\end{array}$ & $\begin{array}{l}\text { Not readily available, Expensive } \\
\text { Not portable, Scanning time lengthy }\end{array}$ & $\begin{array}{l}\text { Limited data but } \\
\text { promising }\end{array}$ \\
\hline$M R P$ & $\begin{array}{l}\text { Magnetic } \\
\text { resonance } \\
\text { perfusion }\end{array}$ & 8 & $\begin{array}{l}\text { Readily available } \\
\text { Whole brain coverage } \\
\text { Can be combined with other } \\
\text { MR-based techniques } \\
\text { Repeatable }\end{array}$ & $\begin{array}{l}\text { Not quantitative for CBF } \\
\text { Not readily available } \\
\text { Not portable }\end{array}$ & $\begin{array}{l}\text { Likely not useful as not } \\
\text { quantitative }\end{array}$ \\
\hline$C T A$ & $\begin{array}{l}\text { Computed } \\
\text { tomography } \\
\text { angiography }\end{array}$ & $\begin{array}{l}\text { Unknown but } \\
\text { likely very low } \\
(<10)\end{array}$ & $\begin{array}{l}\text { Readily available } \\
\text { Rapid acquisition }\end{array}$ & $\begin{array}{l}\text { Exposure to iodinated contrast } \\
\text { Not portable }\end{array}$ & $\begin{array}{l}\text { Limited data but most } \\
\text { promising as ubiquitous } \\
\text { technology }\end{array}$ \\
\hline$C T P$ & $\begin{array}{l}\text { Computed } \\
\text { tomography } \\
\text { perfusion }\end{array}$ & 0 & $\begin{array}{l}\text { Readily available } \\
\text { Rapid acquisition } \\
\text { Rapid acquisition } \\
\text { Quantitative* }\end{array}$ & $\begin{array}{l}\text { Exposure to iodinated contrast and } \\
\text { ionizing radiation } \\
\text { Limited anatomic coverage }(2-4 \mathrm{~cm}) \text {, } \\
\text { Requires post-processing of data, } \\
\text { Relies on intact BBB, Not portable }\end{array}$ & $\begin{array}{l}\text { Limited data but holds } \\
\text { promise, especially if } \\
\text { anatomic coverage } \\
\text { extended }\end{array}$ \\
\hline$T C D$ & $\begin{array}{l}\text { Transcranial } \\
\text { Doppler } \\
\text { Ultrasound }\end{array}$ & Unknown & $\begin{array}{l}\text { Rapid } \\
\text { Non-invasive } \\
\text { Portable }\end{array}$ & $\begin{array}{l}\text { Does not quantify CBF } \\
\text { Difficult to perform, One } \\
\text { measurement for each, hemisphere }\end{array}$ & $\begin{array}{l}\text { Not deemed useful in } \\
\text { NDD }\end{array}$ \\
\hline
\end{tabular}

* controversy exists regarding its true quantitative abilities

death occurs, ${ }^{38}$ these changes become clearly abnormal fairly late after the clinical diagnosis of brain death, ${ }^{38}$ or may not always be visible on MRS. ${ }^{47}$ Non-proton MRS, such as sodium or phosphorus-based techniques, may be potentially more powerful in the assessment of brain death, as they may allow imaging of the ATP-dependent pathways or neuronal membrane integrity. ${ }^{54}$ However, the practical application of these techniques has not yet been validated. Therefore, much like routine CT, conventional MRI, even with DWI and MRS, lacks the sensitivity and specificity to be useful as an ancillary test in the evaluation of brain death.

\section{Ancillary Tests for Cerebral Perfusion}

The other category of ancillary testing revolves around the general concept that brain tissue not receiving blood flow will eventually suffer irreversible damage, leading ultimately to brain (and brainstem) death. This dependence on cerebral perfusion suggests that tools able to accurately assess the presence or absence of CBF would be helpful in the determination of brain death, as would those tests able to demonstrate neuronal viability. However, whereas the absence of $\mathrm{CBF}$ is considered to be an accurate marker of brain death, a person may be brain dead despite the presence of $\mathrm{CBF}$. 


\section{Table 3: Angiographic findings in brain death}

\author{
No visualization of anterior circulation beyond level of \\ supraclinoid ICAs
}

No posterior circulation filling beyond dural penetration of vertebral arteries

Absence of internal cerebral vein filling

ICA=internal carotid arteries

There are two patterns of brain death which may occur, as proposed by Palmer and Bader. ${ }^{35}$ One pattern is manifested by an elevation of intracranial pressure (ICP) to a point exceeding the mean arterial pressure (MAP). As a result, no net CBF is present, eventually leading to permanent cytotoxic injury of the intracranial neuronal tissue. It would then follow that tests relying on demonstrating the presence or absence of CBF could be used to determine brain death in this particular pattern.

The other pattern Palmer and Bader describe is one where the ICP does not exceed the MAP, with maintenance of cerebral perfusion pressure to values where CBF should be sufficient to provide the brain with the necessary oxygen, glucose, and other nutrients to allow its survival. In this pattern, there is an intrinsic pathology affecting the brain's neurons on a cellular level which, if widespread and sustained, can also result in brain death. Such a pattern of brain death would be best assessed by a tool able to determine neuronal function/viability. As CBF would be present in this pattern, tests relying on its absence for determination of brain death would be falsely negative in this setting.

It is important to note that one of the major reasons for the markedly elevated ICP is diffuse intracranial parenchymal swelling. Though the ICP must exceed the MAP for no cerebral perfusion to be present, this swelling is not an indefinite phenomenon. Gradually, the swelling will subside and, if the patient is able to still maintain a reasonable MAP, CBF may eventually return. The clinical diagnosis of brain death would still be made in this setting, and tests for neuronal viability/function would also be able to accurately determine this. However, tests relying on $\mathrm{CBF}$ could again be falsely negative, suggesting that there may be a time-sensitive nature to the examinations using $\mathrm{CBF}$ as a marker of brain death.

There may also be situations where an elevation in ICP resulting in cessation of CBF may not be present. This may occur as a primary phenomenon, as in the case of catastrophic brainstem or cerebellar pathology. ${ }^{13,57}$ Alternatively, this may occur when the rise in ICP has been compensated for or alleviated in some manner. This is a common phenomenon in infants who, because of their open fontanelles and soft, deformable skulls, may show only an attendant increase in their head circumference as a result of situations which would typically cause a markedly raised ICP in those patients with a "closed" cranial vault. Post-traumatic skull fractures may also allow decompression of raised ICP. ${ }^{58}$ Surgical procedures, such as decompressive craniectomies ${ }^{59}$ and placement of ventricular drains, ${ }^{60-62}$ are deliberately done to lower the ICP. As a result of these situations, CBF may be maintained, despite non-viability of the brain itself.

In summary, though the sustained absence of $\mathrm{CBF}$ will eventually lead to brain death, situations where $\mathrm{CBF}$ can be maintained despite documented brain death exist ${ }^{63-65}$ (de Campo 1993; Flowers et al 2000; Kurtek et al 2000). It is important to understand the situations in which these false negative results may arise in order to assess the results in context and consider other options for confirmation of brain death.

\section{Tests for Determining CBF}

\section{Cerebral Angiography}

Among the techniques for determining CBF, cerebral angiography is classically considered to be the reference standard for imaging brain death. Experience in this setting dates back to a landmark paper published by Heiskanen in $1964,{ }^{66}$ with numerous authors since contributing to the body of knowledge regarding four-vessel cerebral angiography as an ancillary test in the determination of brain death. ${ }^{37,38,43,67-69}$ It is relatively simple to perform, can be done within 30-60 minutes, and is relatively straight-forward to interpret. Though early cerebral angiography examinations for brain death were actually done using iodinated contrast injections in the aortic arch, the currently accepted method of assessment is done with separate contrast injections performed in both common or internal carotid arteries, as well as in both vertebral arteries. Classical angiographic findings in brain death are summarized in Table 3, and include the lack of contrast opacification of the internal carotid arteries beyond the carotid siphon, and filling of the vertebral arteries to, but not beyond, their dural penetration.

Despite cerebral angiography being considered the "gold standard" for determination of $\mathrm{CBF}$, there are many concerns with its use. ${ }^{31}$ Cerebral angiography requires specialized neuroradiologic expertise to perform and interpret the procedure. It is an invasive test, requiring the placement of a catheter into the arterial circulation, with injections performed in the cerebrovascular arterial system. Although the risk of procedural complications is low, the potential exists for vessel damage anywhere along the course of the catheter. As well, the patient must be transported to the Radiology Department for the procedure, with the attendant risks this may bring. Its availability is not always immediate, and the cost associated with this examination is not low. Although no false positive cases have been reported, false negative examinations may occur if cerebral angiography is performed on a patient in whom there is no significant elevation of the ICP, ${ }^{37}$ or if angiography is performed in a manner where contrast is injected too vigorously into the downstream circulation, thereby artifactually opacifying the intracranial vasculature. ${ }^{7,38}$ Controversy also exists regarding the potential for iodinated contrast to damage transplantable tissues, such as the kidneys. ${ }^{38}$ As such, though cerebral angiography is a reliable and accurate examination, other options are preferred.

\section{Radionuclide Angiography}

In many ways, radionuclide angiography is the ideal ancillary test in the determination of brain death. $7,31,32,38,48,65,70-72$ It is safe, 
noninvasive, and portable. It is reliable and reproducible, and is in total agreement with cerebral angiography. ${ }^{73}$ When combined with HMPAO SPECT, it has been validated for use in the setting of brain death evaluation. ${ }^{74,75}$ Several good articles review the technique for performing HMPAO SPECT radionuclide angiography as well as expected findings in the setting of brain death. ${ }^{70,76}$ Briefly, there should be no intracranial flow on the dynamic phase of imaging, with no uptake of radionuclide within the brain tissue on planar and SPECT imaging. This is referred to as the "empty skull" sign. Because of the maintained external carotid artery perfusion, the nasal region can be quite prominent. This is referred to as the "hot nose" sign. Variable visualization of the superior sagittal sinus may occur, ${ }^{38,63}$ due to flow in the meningeal arteries and/or drainage of scalp venous blood via transosseous emissary veins. If focal residual brain perfusion is seen, this is interpreted as not confirmatory of brain death and a repeat HMPAO SPECT study is typically performed in 24-48 hours. This residual activity may be seen in two fairly distinct distributions, as described by Facco et al. ${ }^{71}$ Perfusion may be seen in isolated hemispheric structures, such as the thalami or basal ganglia. This is usually seen in children or in adults with skull defects. Persistent perfusion may also be seen selectively in the posterior fossa structures, reflecting a rostrocaudal deterioration of intracranial tissues.

\section{CT Angiography and CT Perfusion}

A natural extension of CT imaging techniques is the application of CT angiography (CTA) and CT perfusion (CTP) for the evaluation of brain death.,32,77-79 Both techniques are readily available on modern multi-detector helical CT scanners, and are simple to implement into practice. According to Widjicks, ${ }^{9}$ CT angiography is well accepted in all European countries, and several non-European countries, as an ancillary test for brain death. It is easily performed, rapidly acquired, requires only an intravenous access, and is not affected by confounding medical factors. The findings are similar to those already described for dynamic CECT in that no intracranial arterial contrast opacification should be seen in the setting of brain death, typically defined as the vertebrobasilar circulation intradurally, as well as above the level of the supraclinoid internal carotid arteries. There is expected visualization of the external carotid arterial system. Leclerc et $\mathrm{al}^{77}$ further refine the diagnostic criteria as lack of visualization of the cortical middle cerebral artery branches, as well as lack of visualization of the internal cerebral veins. Despite its lack of portability, CTA is still highly efficacious ${ }^{8}$ and does not have the procedural risks associated with conventional digital subtraction angiography. However, as iodinated contrast is still required to perform this examination, the potential risk of contrast-mediated tissue injury is still present.

Computed tomography perfusion is a technique already in widespread use for acute stroke imaging. Interestingly, the earliest description of a perfusion-type CT scan was actually done over two decades ago. ${ }^{42}$ In comparison to CTA, which is relatively simple to interpret, CTP requires post-processing of the acquired data in order to generate the mean transit time, CBF and cerebral blood volume maps needed to appropriately assess the intracranial parenchyma. As such, this interpretation is typically done by a neuroradiologist, although, in some institutions, stroke neurologists are also familiar with this technique. Some authors tout CTP as a quantitative tool for measuring $\mathrm{CBF}^{80-83}$ This remains an area of debate, ${ }^{22}$ having yet to be proven in large prospective studies. In the setting of global brain injury, the commonly performed semi-quantitative application of CTP would potentially be a major issue due to its reliance on ratio comparisons to a contralateral "normal" parenchyma. In addition, no technique has yet been developed which allows whole brain coverage through existing CTP techniques, although another level of perfusion imaging can be performed after waiting approximately three-six minutes. Though one may infer that the arterial input function waveform should be flat, there is no actual literature reporting brain death findings on CTP, and its use in the diagnosis of brain death has never been evaluated in a formal fashion.

\section{Xenon $C T$}

Xenon CT (XeCT) is a powerful tool, and has been applied to ischemic cerebrovascular disease for many decades. It provides a quantitative measurement of $\mathrm{CBF},{ }^{84-86}$ and is also noninvasive, fairly rapidly performed, and provides the added benefit of routine CT imaging of the brain as well. Xenon CT has a high spatial resolution, and flow assessment of the entire brain can be sampled accurately with the three levels of examination typically used. Also, by using inhalational Xenon, an inert gas having CT attenuation characteristics similar to iodine, XeCT avoids the use of iodinated contrast, thereby eliminating issues raised regarding contrast-mediated tissue injury (such as contrast-induced nephrotoxicity).

Many authors describe the use of XeCT in brain death. , 32,38,87-89 $^{\text {Thompson et }} \mathrm{l}^{89}$ compared XeCT to dynamic brain scintigraphy in clinically brain dead children, and determined that negligible (defined as $<5 \mathrm{ml} / 100 \mathrm{~g} /$ minute) or no $\mathrm{CBF}$ globally were the CBF parameters required in order to confirm the clinical diagnosis of brain death. Pistoia et $\mathrm{al}^{88}$ confirmed these values in 30 patients they studied over seven years.

Though the practical application of the technique is not difficult, its accessibility is a tremendous challenge, as Xenon CT is virtually unavailable apart from at a select number of academic institutions in North America. Again, the patient must be transported to the Radiology Department, and dedicated Neuroradiology expertise is required to perform and interpret the exam. As such, though XeCT remains an immensely powerful tool for quantitative examination of $\mathrm{CBF}$, too many issues exist to allow its ubiquitous use as an ancillary test for the confirmation of brain death.

\section{Magnetic Resonance Angiography and Perfusion}

As has already been described, conventional MRI performed in the setting of clinically confirmed brain death can demonstrate the lack of normal intracranial arterial flow voids. This is thought to be a consequence of ICP being greater than MAP, thereby resulting in no net intracranial arterial blood flow. Dedicated magnetic resonance angiography (MRA) has been performed to evaluate this finding. ${ }^{32,36,49,90}$ All assessments thus far have utilized a "time-of-flight" (TOF) or "moving blood" imaging technique, without administration of intravenous contrast. Similar findings as those reported on CTA assessment have also 
been reported for TOF-MRA, namely absence of visualization of the vertebro-basilar system intracranially and the internal carotid arteries above the level of the carotid siphons. ${ }^{46}$ External carotid arterial visualization can be seen, as can partial visualization of the superior sagittal sinus for the reasons described earlier. The study by Karantanas et al, ${ }^{36}$ clearly demonstrated continued visualization of the intracranial arterial circulation in 10 patients who had suffered severe closed head injuries and who did not meet clinical criteria for brain death, as opposed to total lack of visualization of intracranial blood flow in the 20 patients who were clinically thought to be brain dead prior to MR examination. All 10 patients survived, with variable neurologic outcomes. All of the 20 patients having no evidence of MRAdocumented intracranial blood flow died.

Controversies exist around the use of MRA for brain death evaluation. Though there are several reports of its use in this setting, no formal evaluations have been done. Because contrastenhanced MRA is not prone to some of the pitfalls of TOF imaging, such as slow flow, in-plane flow, and non-laminar flow, there has been a progressive shift towards its use in the evaluation of cerebrovascular disorders. However, no reports currently exist in the literature on its use in the neurological determination of death. Although MRA is noninvasive, it still requires the transfer of the patient to the MR scanner. Subspecialty neuroradiologic expertise is again required to perform and interpret the examination. The exam takes longer than CTA, is more prone to technique-related image degradation, and requires MR compatability of all devices attached to the patient.

Thus, though MRA holds promise, especially when combined with MRI, MRS, and DWI, it has not as of yet been validated for use as an ancillary test for confirmation of brain death. ${ }^{31}$

The MR perfusion (MRP) is a powerful technique, utilizing first-pass magnetic susceptibility effects of administered contrast agents to obtain data similar to CTP. ${ }^{91}$ Its main advantage are its greater coverage of the brain during perfusion imaging (whole brain imaging versus $2-4 \mathrm{~cm}$ for CTP), as well as the ability to obtain diffusion weighted imaging. However, though the technique can determine $\mathrm{CBF}$ to a lower limit of $8 \mathrm{~mL} / 100 \mathrm{~g} / \mathrm{min}$, MRP is semi-quantitative, and no data is available on its use in the setting of brain death.

\section{Transcranial Duplex Ultrasonography}

The utility of transcranial duplex ultrasonography (TCD) as a test for evaluating the presence of intracranial blood flow has been reviewed elsewhere..$^{32,38,92}$ Classical findings in a patient who is brain dead are short systolic spikes or peaks, oscillating movement of blood within the assessed arteries, and disappearance of systolic flow on subsequent testing when previously documented as present. Transcranial duplex ultrasonography has many potential advantages. It is safe, portable, noninvasive, and relatively rapidly performed. As well, it is relatively inexpensive, and does not require administration of potentially organotoxic contrast agents. However, TCD is not widely available, and is quite labour-intensive, requiring tremendous skill and rigor in its application to insonate all of the major intracranial arteries. ${ }^{31,32,38}$ In addition, up to $20 \%$ of patients may fail TCD scanning as their cranial vaults are too thick to allow appropriate visualization of these arteries. ${ }^{32}$ As well, many authors have reported false positives and negatives using TCD. ${ }^{61,93-95}$ Because of these drawbacks, as well as its lack of validation, TCD is not considered an accurate and reliable ancillary test in the confirmation of brain death.

\section{The Future}

Recognizing that false negatives may occur when an ancillary test evaluating the presence or absence of $\mathrm{CBF}$ is used, techniques assessing for $\mathrm{CBF}$ still appear to be the most promising with respect to a reliable and reproducible diagnosis of brain death in the face of confounding clinical factors. Though CTA has not been accepted for use in North America, its use as an alternative in Europe, and other non-European countries suggests that greater effort be taken to validate it as an ancillary test. Computed tomography perfusion in combination with CTA may be even better; however, no large series of patients have yet been reported and controversy remains regarding its ability to truly quantify CBF. Current advances in MR angiographic techniques in the imaging of cerebrovascular pathology include the use of intravenous contrast agents, ${ }^{96}$ quantitative phase contrast techniques, ${ }^{97-99}$ and time-resolved MRA. ${ }^{100,101}$ In addition, MR perfusion techniques such as arterial spin labelling may contribute to improved characterization of presence or absence of intracranial blood flow. All of these methods may provide a greater certainty of the presence or absence of $\mathrm{CBF}$, thereby ensuring no false positive exams. However, providing accurate and meaningful CBF data regarding the brainstem remains a challenge. In the future, truly quantitative CT- or MR-based perfusion techniques may be developed, thereby allowing CBF assessment as currently only provided by XeCT or PET. In addition, issues regarding the lack of portability of these different modalities are being addressed, as portable CT scanning units are already commercially available, some with Xenon-CT perfusion capability. Other tests incorporating complementary modalities may also be developed.

\section{CONCLUSION}

The diagnosis of brain death remains primarily a clinical determination. However, it is important to recognize that confounding factors do exist that may make clinical diagnosis extremely difficult or impossible. Ancillary tests are then useful in helping make this diagnosis. Tests imaging $\mathrm{CBF}$ are the preferred ancillary tests, with HMPAO SPECT radionuclide angiography considered the first-line study. When this is not available or is equivocal, 4-vessel cerebral angiography is another validated examination which can be performed to determine the presence or absence of CBF. Though several case reports exist describing the use of other noninvasive angiographic or perfusion techniques, such as CTA and MRA, currently none of these techniques have been validated for use as ancillary tests in the determination of brain death. Because of the many potential advantages these noninvasive techniques may offer, further efforts should be made to evaluate them as replacement tests for conventional 4-vessel cerebral angiography.

\section{FUNDING}

Canadian Council for Donation and Transplantation 


\section{REFERENCES}

1. Mollaret P, Goulon M. [The depassed coma (preliminary memoir).]. Rev Neurol. (Paris) 1959 July;101:3-15.

2. A definition of irreversible coma. Report of the Ad Hoc Committee of the Harvard Medical School to Examine the Definition of Brain Death. JAMA. 1968 August 5;205(6):337-40.

3. Chan JY, Chang AY, Chan SH. New insights on brain stem death: from bedside to bench. Prog Neurobiol. 2005 December;77(6): 396-425.

4. Popp E, Bottiger BW. Cerebral resuscitation: state of the art, experimental approaches and clinical perspectives. Neurol Clin. 2006 February;24(1):73-87, vi.

5. Bonetti MG, Ciritella P, Valle G, Perrone E. 99mTc HM-PAO brain perfusion SPECT in brain death. Neuroradiology. 1995 July; 37(5):365-9.

6. An appraisal of the criteria of cerebral death. A summary statement. A collaborative study. JAMA. 1977 March 7;237(10):982-6.

7. Darby JM, Yonas H, Gur D, Latchaw RE. Xenon-enhanced computed tomography in brain death. Arch Neurol. 1987 May; 44(5):551-4.

8. Practice parameters for determining brain death in adults (summary statement). The Quality Standards Subcommittee of the American Academy of Neurology. Neurology. 1995 May; 45(5):1012-4.

9. Wijdicks EF. Brain death worldwide: accepted fact but no global consensus in diagnostic criteria. Neurology. 2002 January 8; 58(1):20-5

10. Young B, Blume W, Lynch A. Brain death and the persistent vegetative state: similarities and contrasts. Can J Neurol Sci. 1989 November; 16(4):388-93.

11. Guidelines for the diagnosis of brain death. Canadian Neurocritical Care Group. Can J Neurol Sci. 1999 February;26(1):64-6.

12. Baron L, Shemie SD, Teitelbaum J, Doig CJ. Brief review: history, concept and controversies in the neurological determination of death. Can J Anaesth. 2006 June;53(6):602-8.

13. Bernat JL. The concept and practice of brain death. Prog Brain Res. 2005;150:369-79.

14. Astrup J. Energy-requiring cell functions in the ischemic brain. Their critical supply and possible inhibition in protective therapy. J Neurosurg. 1982 April;56(4):482-97.

15. Branston NM, Ladds A, Symon L, Wang AD. Comparison of the effects of ischaemia on early components of the somatosensory evoked potential in brainstem, thalamus, and cerebral cortex. J Cereb Blood Flow Metab. 1984 March;4(1):68-81.

16. Hossmann KA, Schuier FJ. Experimental brain infarcts in cats. I. Pathophysiological observations. Stroke. 1980 November;11(6): 583-92.

17. Jones TH, Morawetz RB, Crowell RM, Marcoux FW, FitzGibbon SJ, DeGirolami U, et al. Thresholds of focal cerebral ischemia in awake monkeys. J Neurosurg. 1981 June;54(6):773-82.

18. Markus HS. Cerebral perfusion and stroke. J Neurol Neurosurg Psychiatry. 2004 March;75(3):353-61.

19. Siesjo BK. Pathophysiology and treatment of focal cerebral ischemia. Part I: Pathophysiology. J Neurosurg. 1992 August; 77(2):169-84

20. Lassen NA. The luxury-perfusion syndrome and its possible relation to acute metabolic acidosis localised within the brain. Lancet. 1966 November 19;2(7473):1113-5.

21. Robertson CS, Narayan RK, Gokaslan ZL, Pahwa R, Grossman $\mathrm{RG}$, et al. Cerebral arteriovenous oxygen difference as an estimate of cerebral blood flow in comatose patients. J Neurosurg. 1989 February;70(2):222-30.

22. Latchaw RE, Yonas H, Hunter GJ, Yuh WT, Ueda T, Sorensen AG, et al. Guidelines and recommendations for perfusion imaging in cerebral ischemia: A scientific statement for healthcare professionals by the writing group on perfusion imaging, from the Council on Cardiovascular Radiology of the American Heart Association. Stroke. 2003 April;34(4):1084-104.

23. Heiss WD, Hayakawa T, Waltz AG. Cortical neuronal function during ischemia. Effects of occlusion of one middle cerebral artery on single-unit activity in cats. Arch Neurol. 1976 December;33(12):813-20
24. Branston NM, Symon L, Crockard HA, Pasztor E. Relationship between the cortical evoked potential and local cortical blood flow following acute middle cerebral artery occlusion in the baboon. Exp Neurol. 1974 November;45(2):195-208.

25. Sharbrough FW, Messick JM, Jr., Sundt TM, Jr. Correlation of continuous electroencephalograms with cerebral blood flow measurements during carotid endarterectomy. Stroke. 1973 July; 4(4):674-83.

26. Harris RJ, Symon L, Branston NM, Bayhan M. Changes in extracellular calcium activity in cerebral ischaemia. J Cereb Blood Flow Metab. 1981;1(2):203-9.

27. Lang EW, Chesnut RM. Intracranial pressure and cerebral perfusion pressure in severe head injury. New Horiz. 1995 August;3(3): 400-9.

28. Paulson OB, Strandgaard S, Edvinsson L. Cerebral autoregulation. Cerebrovasc Brain Metab Rev. 1990;2(2):161-92.

29. Grande PO, Asgeirsson B, Nordstrom CH. Volume-targeted therapy of increased intracranial pressure: the Lund concept unifies surgical and non-surgical treatments. Acta Anaesthesiol Scand. 2002 September;46(8):929-41.

30. Lang CJ, Heckmann JG. Apnea testing for the diagnosis of brain death. Acta Neurol Scand. 2005 December;112(6):358-69.

31. Shemie SD, Doig C, Dickens B, Byrne P, Wheelock B, Rocker G, et al. Severe brain injury to neurological determination of death: Canadian forum recommendations. CMAJ. 2006 March 14;174(6):S1-13.

32. Young GB, Lee D. A critique of ancillary tests for brain death. Neurocrit Care. 2004;1(4):499-508.

33. Kohrman MH, Spivack BS. Brain death in infants: sensitivity and specificity of current criteria. Pediatr Neurol. 1990 January; 6(1):47-50.

34. Wijdicks EF. The diagnosis of brain death. N Engl J Med. 2001 April 19;344(16):1215-21.

35. Palmer S, Bader MK. Brain tissue oxygenation in brain death. Neurocrit Care. 2005;2(1):17-22.

36. Karantanas AH, Hadjigeorgiou GM, Paterakis K, Sfiras D, Komnos A. Contribution of MRI and MR angiography in early diagnosis of brain death. Eur Radiol. 2002 November;12(11):2710-6.

37. Marrache F, Mégarbane B, Pirnay S, Rhaoui A, Thuong M. Difficulties in assessing brain death in a case of benzodiazepine poisoning with persistent cerebral blood flow. Hum Exp Toxicol. 2004 October;23(10):503-5.

38. Monsein LH. The imaging of brain death. Anaesth Intensive Care. 1995 February;23(1):44-50.

39. Yoshikai T, Tahara T, Kuroiwa T, Kato A, Uchino A, Abe M, et al. Plain CT findings of brain death confirmed by hollow skull sign in brain perfusion SPECT. Radiat Med. 1997 November; 15(6):419-24

40. Dominguez-Roldan JM, Jimenez-Gonzalez PI, Garcia-Alfaro C, Hernandez-Hazañas F, Murillo-Cabezas F, Perez-Bernal J. Identification by CT scan of ischemic stroke patients with high risk of brain death. Transplant Proc. 2004 November;36(9): 2562-3.

41. Geraghty MC, Torbey MT. Neuroimaging and serologic markers of neurologic injury after cardiac arrest. Neurol Clin. 2006 February;24(1):107-21, vii.

42. Arnold H, Kuhne D, Rohr W, Heller M. Contrast bolus technique with rapid CT scanning. A reliable diagnostic tool for the determination of brain death. Neuroradiology. 1981;22(3): 129-32.

43. Dupas B, Gayet-Delacroix M, Villers D, Antonioli D, Veccherini MF, Soulillou JP. Diagnosis of brain death using two-phase spiral CT. AJNR Am J Neuroradiol. 1998 April;19(4):641-7.

44. Tan WS, Wilbur AC, Jafar JJ, Spigos DG, Abejo R. Brain death: use of dynamic CT and intravenous digital subtraction angiography. AJNR Am J Neuroradiol. 1987 January;8(1):123-5.

45. Lee DH, Nathanson JA, Fox AJ, Pelz DM, Lownie SP. Magnetic resonance imaging of brain death. Can Assoc Radiol J. 1995 June;46(3): 174-8.

46. Matsumura A, Meguro K, Tsurushima H, Komatsu Y, Kikuchi Y, Wada M, et al. Magnetic resonance imaging of brain death. Neurol Med Chir. (Tokyo) 1996 March;36(3):166-71. 
47. Progressive brain failure after diffuse hypoxic ischemic brain injury: a serial MR and proton MR spectroscopic study. AJNR Am J Neuroradiol. 1998 April;19(4):648-52.

48. Jones KM, Barnes PD. MR diagnosis of brain death. AJNR Am J Neuroradiol. 1992 January;13(1):65-6.

49. Lovblad KO, Bassetti C. Diffusion-weighted magnetic resonance imaging in brain death. Stroke. 2000 February;31(2):539-42.

50. McKinney AM, Teksam M, Felice R, Casey SO, Cranford R, Truwit $\mathrm{CL}$, et al. Diffusion-weighted imaging in the setting of diffuse cortical laminar necrosis and hypoxic-ischemic encephalopathy. AJNR Am J Neuroradiol. 2004 November; 25(10):1659-65.

51. Kumada K, Fukuda A, Yamane K, Horiuchi I, Kohama A, Hirano K, et al. [Diffusion-weighted imaging of brain death: study of apparent diffusion coefficient]. No To Shinkei. 2001 November; 53(11): 1027-31.

52. Nakahara M, Ericson K, Bellander BM. Diffusion-weighted MR and apparent diffusion coefficient in the evaluation of severe brain injury. Acta Radiol. 2001 July;42(4):365-9.

53. Sener RN. Diffusion MRI in the postmortem brain: case report. J Neuroradiol. 2004 December;31(5):406-8.

54. Aichner F, Felber S, Birbamer G, Luz G, Judmaier W, Schmutzhard E. Magnetic resonance: a noninvasive approach to metabolism, circulation, and morphology in human brain death. Ann Neurol. 1992 October;32(4):507-11.

55. Garde K, Mortensen AC, Toft PB, Sørensen MB, Madsen FF, Henriksen $\mathrm{O}$. Phosphorous and proton spectroscopy in relation to near incarceration and incarceration of the human brain. Acta Radiol. 1994 March;35(2):197-200.

56. Terk MR, Gober JR, DeGiorgio C, Wu P, Colletti PM. Brain death in the neonate: assessment with P-31 MR spectroscopy. Radiology. 1992 February;182(2):582-3.

57. Kosteljanetz M, Ohrstrom JK, Skjodt S, Teglbjaerg PS. Clinical brain death with preserved cerebral arterial circulation. Acta Neurol Scand. 1988 November;78(5):418-21

58. Alvarez LA, Lipton RB, Hirschfeld A, Salamon O, Lantos G. Brain death determination by angiography in the setting of a skull defect. Arch Neurol. 1988 February;45(2):225-7.

59. Braum M, Ducrocq X, Huot JC, Audibert G, Anxionnat R, Picard L. Intravenous angiography in brain death: report of 140 patients. Neuroradiology. 1997 June;39(6):400-5

60. Hansen AV, Lavin PJ, Moody EB, Sandler MP. False-negative cerebral radionuclide flow study, in brain death, caused by a ventricular drain. Clin Nucl Med. 1993 June;18(6):502-5.

61. Petty GW, Mohr JP, Pedley TA, Tatemichi TK, Lennihan L, Duterte DI, et al. The role of transcranial Doppler in confirming brain death: sensitivity, specificity, and suggestions for performance and interpretation. Neurology. 1990 February;40(2):300-3.

62. Pribram HF. Angiographic appearances in acute intracranial hypertension. Neurology. 1961 January;11:10-21.

63. de Campo MP. Imaging of brain death in neonates and young infants. J Paediatr Child Health. 1993 August;29(4):255-8.

64. Flowers WM, Jr., Patel BR. Persistence of cerebral blood flow after brain death. South Med J. 2000 April;93(4):364-70.

65. Kurtek RW, Lai KK, Tauxe WN, Eidelman BH, Fung JJ. Tc-99m hexamethylpropylene amine oxime scintigraphy in the diagnosis of brain death and its implications for the harvesting of organs used for transplantation. Clin Nucl Med. 2000 January;25(1): 7-10.

66. Heiskanen O. Cerebral circulatory arrest caused by acute increase of intracranial pressure. A clinical and roentgenological study of 25 cases. Acta Neurol Scand Suppl. 1964;40:Suppl.7:1-57.

67. Bergquist E, Bergstrom K. Angiography in cerebral death. Acta Radiol Diagn. (Stockh) 1972 May;12(3):283-8.

68. Bradac GB, Simon RS. Angiography in brain death. Neuroradiology. 1974;7(1):25-8.

69. Wilkening M, Louvier N, D'Athis P, Freysz M. [Validity of cerebral angiography via venous route in the diagnosis of brain death]. Bull Acad Natl Med. 1995 January;179(1):41-8.

70. Al-Shammri S, Al-Feeli M. Confirmation of brain death using brain radionuclide perfusion imaging technique. Med Princ Pract. 2004 September;13(5):267-72.
71. Facco E, Zucchetta P, Munari M, Baratto F, Behr AU, Gregianin M, et al. $99 \mathrm{mTc}-\mathrm{HMPAO}$ SPECT in the diagnosis of brain death. Intensive Care Med. 1998 September;24(9):911-7.

72. Okuyaz C, Gücüyener K, Karabacak NI, Aydin K, Serdaroğlu A, Cingi E. Tc-99m-HMPAO SPECT in the diagnosis of brain death in children. Pediatr Int. 2004 December;46(6):711-4.

73. Munari M, Zucchetta P, Carollo C, Gallo F, De Nardin M, Marzola $\mathrm{MC}$, et al. Confirmatory tests in the diagnosis of brain death: comparison between SPECT and contrast angiography. Crit Care Med. 2005 September;33(9):2068-73.

74. Weckesser M, Schober O. Brain death revisited: utility confirmed for nuclear medicine. Eur J Nucl Med. 1999 November; 26(11):1387-91.

75. Wieler H, Marohl K, Kaiser KP, Klawki P, Frössler H. Tc-99m HMPAO cerebral scintigraphy. A reliable, noninvasive method for determination of brain death. Clin Nucl Med. 1993 February;18(2):104-9.

76. Vander Borght T, Laloux P, Maes A, Salmon E, Goethals I, Goldman S. Guidelines for brain radionuclide imaging. Perfusion single photon computed tomography (SPECT) using Tc-99m radiopharmaceuticals and brain metabolism positron emission tomography (PET) using F-18 fluorodeoxyglucose. The Belgian Society for Nuclear Medicine. Acta Neurol Belg. 2001 December;101(4):196-209.

77. Leclerc X, Taschner CA, Vidal A, Strecker G, Savage J, Gauvrit JY, et al. The role of spiral CT for the assessment of the intracranial circulation in suspected brain-death. J Neuroradiol. 2006 April;33(2):90-5.

78. Qureshi AI, Kirmani JF, Xavier AR, Siddiqui AM. Computed tomographic angiography for diagnosis of brain death. Neurology. 2004 February 24;62(4):652-3.

79. Yu SL, Lo YK, Lin SL, Lai PH, Huang WC. Computed tomographic angiography for determination of brain death. J Comput Assist Tomogr. 2005 July;29(4):528-31.

80. Abe H, Murakami T, Kubota M, Kim T, Hori M, Kudo M, et al. Quantitative tissue blood flow evaluation of pancreatic tumor: comparison between xenon CT technique and perfusion CT technique based on deconvolution analysis. Radiat Med. 2005 August; 23(5):364-70.

81. Kudo K, Terae S, Katoh C, Oka M, Shiga T, Tamaki N, et al. Quantitative cerebral blood flow measurement with dynamic perfusion CT using the vascular-pixel elimination method: comparison with $\mathrm{H} 2(15) \mathrm{O}$ positron emission tomography. AJNR Am J Neuroradiol. 2003 March;24(3):419-26.

82. Schaefer PW, Roccatagliata L, Ledezma C, Hoh B, Schwamm LH, Koroshetz W, et al. First-pass quantitative CT perfusion identifies thresholds for salvageable penumbra in acute stroke patients treated with intra-arterial therapy. AJNR Am J Neuroradiol. 2006 January;27(1):20-5.

83. Wintermark M, Thiran JP, Maeder P, Schnyder P, Meuli R. Simultaneous measurement of regional cerebral blood flow by perfusion CT and stable xenon CT: a validation study. AJNR Am J Neuroradiol. 2001 May;22(5):905-14.

84. DeWitt DS, Fatouros PP, Wist AO, Stewart LM, Kontos HA, Hall JA, et al. Stable xenon versus radiolabeled microsphere cerebral blood flow measurements in baboons. Stroke. 1989 December; 20(12):1716-23.

85. Fatouros PP, Wist AO, Kishore PR, DeWitt DS, Hall JA, Keenan $\mathrm{RL}$, et al. Xenon/computed tomography cerebral blood flow measurements. Methods and accuracy. Invest Radiol. 1987 September;22(9):705-12.

86. Gur D, Yonas H, Jackson DL, Wolfson SK Jr, Rockette H, Good WF, et al. Measurement of cerebral blood flow during xenon inhalation as measured by the microspheres method. Stroke. 1985 September;16(5):871-4.

87. Ashwal S, Schneider S. Brain death in the newborn. Pediatrics. 1989 September;84(3):429-37

88. Pistoia F, Johnson DW, Darby JM, Horton JA, Applegate LJ, Yonas $\mathrm{H}$. The role of xenon CT measurements of cerebral blood flow in the clinical determination of brain death. AJNR Am J Neuroradiol. 1991 January;12(1):97-103. 
89. Thompson JR, Ashwal S, Schneider S, Hasso AN, Hinshaw DB Jr, Kirk G. Comparison of cerebral blood flow measurements by xenon computed tomography and dynamic brain scintigraphy in clinically brain dead children. Acta Radiol Suppl. 1986;369: 675-9.

90. Ishii K, Onuma T, Kinoshita T, Shiina G, Kameyama M, Shimosegawa Y. Brain death: MR and MR angiography. AJNR Am J Neuroradiol. 1996 April;17(4):731-5.

91. Wintermark M, Sesay M, Barbier E, Borbély K, Dillon WP, Eastwood JD, et al. Comparative overview of brain perfusion imaging techniques. Stroke. 2005 September;36(9):e83-e99.

92. Young GB, Shemie SD, Doig CJ, Teitelbaum J. Brief review: the role of ancillary tests in the neurological determination of death. Can J Anaesth. 2006 June;53(6):620-7.

93. de Freitas GR, André C, Bezerra M, Nunes RG, Vincent M. Persistence of isolated flow in the internal carotid artery in brain death. J Neurol Sci. 2003 June 15;210(1-2):31-4.

94. Nau R, Prange HW, Klingelhöfer J, Kukowski B, Sander D, Tchorsch R, et al. Results of four technical investigations in fifty clinically brain dead patients. Intensive Care Med. 1992; 18(2):82-8.

95. Rodriguez RA, Cornel G, Alghofaili F, Hutchison J, Nathan HJ. Transcranial Doppler during suspected brain death in children: potential limitation in patients with cardiac "shunt". Pediatr Crit Care Med. 2002 April;3(2):153-7.

96. Prince MR, Meaney JF. Expanding role of MR angiography in clinical practice. Eur Radiol. 2006 February;16 Suppl 2:B3-B8.
97. Langer DJ, Lefton DR, Ostergren L, Brockington CD, Song J, Niimi Y, et al. Hemispheric revascularization in the setting of carotid occlusion and subclavian steal: a diagnostic and management role for quantitative magnetic resonance angiography? Neurosurgery. 2006 March;58(3):528-33.

98. Neff KW, Horn P, Schmiedek P, Düber C, Dinter DJ. 2D cine phasecontrast MRI for volume flow evaluation of the brain-supplying circulation in moyamoya disease. AJR Am J Roentgenol. 2006 July;187(1):W107-W115.

99. Oktar SO, Yücel C, Karaosmanoglu D, Akkan K, Ozdemir H, Tokgoz N, et al. Blood-flow volume quantification in internal carotid and vertebral arteries: comparison of 3 different ultrasound techniques with phase-contrast MR imaging. AJNR Am J Neuroradiol. 2006 February;27(2):363-9.

100. Cashen TA, Carr JC, Shin W, Walker MT, Futterer SF, Shaibani A, et al. Intracranial time-resolved contrast-enhanced MR angiography at 3T. AJNR Am J Neuroradiol. 2006 April; 27(4):822-9.

101. Meckel S, Mekle R, Taschner C, Haller S, Scheffler K, Radue EW, et al. Time-resolved 3D contrast-enhanced MRA with GRAPPA on a 1.5-T system for imaging of craniocervical vascular disease: initial experience. Neuroradiology. 2006 May;48(5):291-9. 